\title{
Diet, behaviour and cognitive functions: a psychobiological view
}

\author{
John Blundell, Deepa Gumaste, Rowena Handley and \\ Louise Dye \\ PsychoBiology Group, School of Psychology, University of Leeds, Leeds, UK
}

Abstract

There is a rapidly growing interest in the scientific study of the effects of foods on psychological processes involved in the control of behaviour (performance) and cognitive functions such as memory, perception, attention and vigilance. This study forms part of innovative research on functional foods, which provides an active arena for collaboration between researchers in universities, institutes and industry. Research outputs will inform legislation currently being drawn up in Europe. This article describes some basic issues of functional food research exemplified by evidence on the effects of carbohydrate foods. These effects implicate glucose metabolism in some aspects of human memory and performance. One specific issue concerns the problem of daytime lethargy and the "post-lunch dip". An exciting prospect for this type of work is the potential to develop foods to maintain or improve performance in the working environment and to enhance quality of life.

Keywords: blood glucose; memory; post-lunch dip; cognitive performance; carbohydrates

\section{Background}

Traditionally, Eastern medicine has used foods and other edible materials to evoke changes in behaviour, mood and thought processes. Examples are traditional Chinese medicine (TCM) and foods for specified health use (FOSHU) in Japan, and these represent the interface between Eastern and Western ideologies regarding food-health interrelationships. The concept of functional foods (or nutraceuticals) embodies these ideas. Its study has been a foreground for the active interaction between scientific, political and industrial domains. Recently, these ideas have inspired an Institute of Life Sciences (ILSI)-European Union (EU) project termed Functional Food Science in Europe (FUFOSE) (1). Another collaborative project, involving European food industries and academic researchers, is currently examining the status of food claims. This project, named Process for the Assessment of the Scientific Support for Claims on Foods (PASSCLAIM), regards scientific evidence as instrumental in separating truth from hyperbole. Importantly, the FUFOSE and PASSCLAIM projects have identified two types of claims, termed A and B. The type A claim involves a statement about "enhanced function" (e.g. a given food improves concentration), whereas a type B claim refers to a "reduction in disease" (e.g. a certain food prevents heart disease).

Investigations into the effects of foods often involve the identification of intermediate markers, sometimes called biomarkers, in the causal processes linking food ingestion with an endpoint. The conceptual scheme that underlies the VINNOVA project has been designed to investigate the functional properties of certain types of food. Fig. 1 shows how the metabolic effects of foods can be related to their effects on satiety (appetite control), cognitive performance and mood. This novel programme has been designed to map the effects of foods on satiety and performance, while simultaneously seeking to identify biomarkers for both phenomena.

The more remarkable claims about foods typically refer to their effects on mental capacities, which are known as cognitive functions or cognitions, and this area is of considerable research interest. Cognitive functions are mental activities that allow organisms, including humans, to perceive, understand and act upon the environment, thereby optimizing adaptation and performance. The development of cognitive abilities through evolution has 


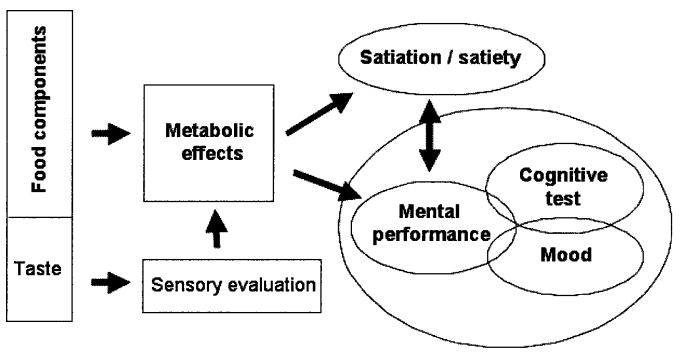

Fig. 1. Effects of food components on satiation, satiety and mental performance and their metabolic correlates.

permitted certain species to master their environment. Brain processes that provide accurate perception and memory of environmental events enable organisms to function successfully. Given their critical importance in human functioning, cognitions are usually operating at a high level, and may be protected from degradation by applying extra effort. Consequently, demonstrating the effect of dietary (or other) interventions on performance is typically difficult.

In humans, cognitive abilities are fundamental in everyday tasks, such as driving, operating machinery and academic work. These complex skills are composed of a number of individual cognitive processes, such as attention to, and perception of, the environment, the acquisition, storage, organization and retrieval of information, and the organization of effective response patterns. These processes (commonly known as concentrating, thinking, remembering and acting) direct the design of laboratory-based tests of individual cognitive functions. The validity and sensitivity of these tests are crucial to any methodology professing to assess the effects of foods and food components on cognitive functioning.

This article describes the effects of carbohydrates (CHO) on cognitions and moods, as mediated via changes in the availability of blood glucose. Furthermore, it discusses the relevance of this work to the "post-lunch dip" (PLD). Finally, it articulates the factors that are important in designing studies that aim to explore the effects of glucose on cognition.

\section{Glucose as neural fuel}

Glucose is the only metabolic fuel available to the brain. It is required for the synthesis of neurotransmitters such as serotonin (5-hydroxytryptamine, 5HT), noradrenaline (NA) and acetylcholine (ACh). Other mechanisms influence cognition, e.g. 5-HT availability, which in turn may be influenced by $\mathrm{CHO} /$ protein intake, by altering the ratio of tryptophan:large neutral amino acids.

\section{Effects of glucose on cognition and mood}

The normal level of blood glucose is $4-5.5 \mathrm{mmol}$ $1^{-1}$. This is controlled by a series of hormonal mechanisms. When it falls below $2.2 \mathrm{mmol}^{-1}$, hypoglycaemia occurs. The decline in glucose, occurring in both mild and severe hypoglycaemia, impairs performance (2). Subjective effects of neuroglycopenia (low blood glucose at the neuronal level) include negative mood (e.g. increased tension and anger) and attenuated arousal (e.g. drowsiness).

Numerous reports suggest that memory is particularly affected by changes in glucose availability. Verbal memory and concept formation, in particular, are the most commonly affected cognitive functions in type II diabetes (2). However, these functions are not impaired in experimentally induced hypoglycaemia. A series of studies in elderly subjects showed that glucose enhanced (short-term) working memory (3).

Glucose administration has reportedly been shown to benefit memory in young adults and the elderly (4). In one study, the performance of subjects who had consumed breakfast, and those who had not, was compared on three memory tasks (5). The "no breakfast" condition was associated with poorer recall, but this effect was reversed by the administration of a glucose drink at breakfast time, in two of the three memory tasks.

The effects of glucose on cognition are summarized in Table 1.

Recovery from nadir and rising levels of blood glucose were associated with better recall than were falling blood glucose levels $(18,19)$. The effect of 50 g glucose on memory for trigrams depends on the initial blood glucose levels of the subject (8) (Fig. 2). Those with higher levels of blood glucose showed better performance. However, after the glucose drink, falling levels of blood glucose were associated with better memory performance. The decline in blood glucose during task performance is thought to indicate that increased neural uptake of glucose results in better memory.

One study found that a high $\mathrm{CHO}$ drink enhanced the number of words correctly recalled, compared with a low CHO drink (9). Moreover, a change in blood glucose was a significant covariate in the high $\mathrm{CHO}$ condition, but not in the low $\mathrm{CHO}$ 
Table I. Effects of glucose on cognition

\begin{tabular}{|c|c|c|c|c|c|}
\hline Reference & Sample & Study design & Cognitive testing & Results & Comments \\
\hline $\begin{array}{l}\text { Deijen et al. } \\
(6)\end{array}$ & $\begin{array}{l}21 \text { cadets ( } 2 \text { groups of } \\
10 \text { and } 11 \text { receiving } 2 \\
\text { different drinks) }\end{array}$ & $\begin{array}{l}5 \text { daily doses of an isocaloric drink ( } 255 \mathrm{kcal}) \text { : } \\
\text { protein-rich drink ( } 2 \mathrm{~g} \text { tyrosine); } \mathrm{CHO} \text {-rich drink }\end{array}$ & $\begin{array}{l}\text { Memory task. Assessment before the combat course } \\
\text { and on the } 6 \text { th day of the course }\end{array}$ & $\begin{array}{l}\text { Group with the tyrosine-rich drink performed better on a } \\
\text { memory task than the group consuming the } \mathrm{CHO} \text {-rich drink }\end{array}$ & Between-subjects design \\
\hline $\begin{array}{l}\text { Benton et al. } \\
\text { (7) }\end{array}$ & 70 young $F$ students & $\begin{array}{l}\text { Glucose drink }(50 \mathrm{~g}) \text { after baseline and } 25 \mathrm{~g} 25 \text { min later or } \\
\text { CHO-free placebo drinks (sweetened with aspartame and } \\
\text { acesulfame K) }\end{array}$ & Memory task & $\begin{array}{l}\text { Improved recall after glucose drink. No differential effect on } \\
\text { primacy or recency }\end{array}$ & $\begin{array}{l}\text { Between subjects. No dietary restrictions on } \\
\text { test day }\end{array}$ \\
\hline $\begin{array}{l}\text { Martin and } \\
\text { Benton (8) }\end{array}$ & $80 \mathrm{~F}$ students & $\begin{array}{l}4 \text { groups: breakfast and } 50 \mathrm{~g} \text { glucose drink }(n=28) ; \\
\text { breakfast and placebo drink }(n=25) \text {; fasted and } 50 \mathrm{~g} \\
\text { glucose drink }(n=12) ; \text { fasted and placebo drink }(n=15)\end{array}$ & Brown-Petersen memory task & $\begin{array}{l}\text { Poorer performance after fasting. Glucose improved memory in } \\
\text { fasted subjects. Breakfast consumption associated with better } \\
\text { memory. Rapidly falling blood glucose associated with better } \\
\text { memory }\end{array}$ & $\begin{array}{l}\text { Between subjects. Nature of breakfast con- } \\
\text { sumed not known/controlled }\end{array}$ \\
\hline Metzger (9) & $\begin{array}{l}23 \text { young } \mathrm{F} \text { and } \mathrm{II} \mathrm{M} \\
\text { students }\end{array}$ & $\begin{array}{l}2 \text { groups: } 50 \mathrm{~g} \text { glucose in drink }(5 \mathrm{M}, 12 \mathrm{~F}) ; 23.7 \mathrm{mg} \text { saccharin } \\
\text { in drink (6M, IIF) }\end{array}$ & Facial recognition task & $\begin{array}{l}\text { No difference in target identification between saccharin/glucose } \\
\text { consumption before test. Fewer false positives and enhanced } \\
\text { signal detection after glucose drink }\end{array}$ & $\begin{array}{l}\text { Between subjects. Restrained from eating or } \\
\text { drinking anything but water for } 9 \mathrm{~h} \text { before } \\
\text { test }\end{array}$ \\
\hline $\begin{array}{l}\text { Green et al. } \\
(10)\end{array}$ & $\begin{array}{l}26 \text { young } \mathrm{M} \text { and } \mathrm{F} \\
\text { students }\end{array}$ & $\begin{array}{l}4 \text { groups: glucose drink }(\times 2) \text {; aspartame (placebo) drink } \\
(\times 2)\end{array}$ & $\begin{array}{l}\text { Two-finger tapping task. Adaptation of Sternberg } \\
\text { recognition memory task (1966). Verbal free recall } \\
\text { task. Bakan task }\end{array}$ & $\begin{array}{l}\text { Glucose enhanced recognition memory times. Enhanced Bakan } \\
\text { performance compared with control }\end{array}$ & $\begin{array}{l}\text { Within subjects. Abstinence from food/glu- } \\
\text { cose or sucrose-containing drinks and } \\
\text { strenuous exercise for } 8 \mathrm{~h}\end{array}$ \\
\hline $\begin{array}{l}\text { Foster et al. } \\
\text { (II) }\end{array}$ & 30 young $F$ students & $\begin{array}{l}3 \text { groups: } 25 \mathrm{~g} \text { glucose drink after baseline; } 37.5 \mathrm{mg} \\
\text { saccharin drink (placebo); } 300 \mathrm{ml} \text { water (placebo) }\end{array}$ & $\begin{array}{l}\text { Memory: immediate, short delay and long-term long } \\
\text { delay; long-term non-verbal (Rey-Osterrieth com- } \\
\text { plex figure drawing, 1944); working memory span } \\
\text { (Wechsler, 1981, 1984) }\end{array}$ & $\begin{array}{l}\text { Glucose facilitation of long-term verbal free and cued recall. No } \\
\text { effect on short-term verbal memory or long-term non-verbal } \\
\text { memory }\end{array}$ & Between subjects \\
\hline \multirow[t]{2}{*}{$\begin{array}{l}\text { Kelly et al. } \\
\text { (12) }\end{array}$} & $\begin{array}{l}\text { Experiment I: } 2 \\
\text { groups of } 6 \text { subjects }\end{array}$ & $\begin{array}{l}4 \text { lunches varying in energy and fat and CHO content: LF/ } \\
\text { low energy ( } 431 \mathrm{kcal}) ; \mathrm{HF} / \mathrm{high} \text { energy ( } 844 \mathrm{kcal}) ; \mathrm{LCHO} \\
\text { low energy ( } 432 \mathrm{kcal}) ; \mathrm{HCHO} / \mathrm{high} \text { energy }(840 \mathrm{kcal})\end{array}$ & $\begin{array}{l}\text { Number recognition task; repeated acquisition task. } \\
\text { Assessment before and after consuming lunch } \\
\text { (experiment I); after breakfast and lunch (experi- } \\
\text { ment 2) }\end{array}$ & $\begin{array}{l}\text { In both experiments: performance on the tasks was poorer after } \\
\text { than before the meal; there were no systematic variations in } \\
\text { performance as a consequence of either the energy or } \\
\text { macronutrient content of the meals }\end{array}$ & $\begin{array}{l}\text { Limited number of subjects and dimension } \\
\text { measured. Subjects allowed to choose among } \\
\text { the tasks. Unrestricted access to caffeine and } \\
\text { nicotine }\end{array}$ \\
\hline & $\begin{array}{l}\text { Experiment 2: } 2 \\
\text { groups of } 6 \text { subjects }\end{array}$ & $\begin{array}{l}\text { Breakfast, lunch and afternoon snack different in energy, fat } \\
\text { and CHO content: LF ( } 739 \mathrm{kcal}) ; \mathrm{MF} \text { (1233 kcal); HF (1685 } \\
\text { kcal); LCHO (703 kcal); MCHO (1213 kcal); HCHO (1666 } \\
\text { kcal) }\end{array}$ & & & \\
\hline $\begin{array}{l}\text { Lloyd et al. } \\
\text { (13) }\end{array}$ & $\begin{array}{l}18 \text { subjects }(3 \mathrm{M} \text {, } \\
15 \mathrm{~F}) \text {, mean age } 27 \text { years }\end{array}$ & $\begin{array}{l}3 \text { isocaloric lunches (about } 700 \mathrm{kcal}) \text { : LF/HCHO (694 kcal, } \\
29 / 54 \% \text { energy); MF/MCHO (706 kcal, } 45 / 42 \% \text { energy); HF/ } \\
\text { LCHO (720 kcal, } 62 / 24 \% \text { energy) }\end{array}$ & $\begin{array}{l}\text { Free recall task (memory). Assessment } 30 \text { min before } \\
\text { lunch, 30, } 90 \text { and } 150 \text { min after finishing lunch }\end{array}$ & No effect on memory & \\
\hline $\begin{array}{l}\text { Lluch et al. } \\
\text { (14) }\end{array}$ & $\begin{array}{l}32 \text { volunteers ( } 16 \mathrm{M}, \\
16 \mathrm{~F}) ; 17 \mathrm{LF} \text { and } 15 \mathrm{HF} \\
\text { consumers }\end{array}$ & $\begin{array}{l}2 \text { isocaloric breakfast }(410 \mathrm{kcal}) \text { and lunches }(740 \mathrm{kcal} \text { for } \mathrm{F}, \\
990 \text { kcal for M); LF/HCHO (breakfast: } 22 / 67 \% \text { energy; lunch: } \\
20 / 61 \% \text { energy); HF/LCHO (breakfast: } 48 / 42 \% \text { energy, } \\
\text { lunch: } 54 / 32 \% \text { energy) }\end{array}$ & $\begin{array}{l}\text { Associative memory (code substitution). Assessment } \\
\text { just before and } 30 \mathrm{~min} \text { after finishing lunch }\end{array}$ & $\begin{array}{l}\text { No effect on memory task. No effect of habitual diet on } \\
\text { performance }\end{array}$ & \\
\hline $\begin{array}{l}\text { Kanarek and } \\
\text { Swinney (15) }\end{array}$ & $\begin{array}{l}\text { Experiment I: } 16 \mathrm{M} \\
\text { (19-22 years) }\end{array}$ & $\begin{array}{l}4 \text { conditions: breakfast ( } 300 \text { kcal) followed by: lunch + } \\
\text { caloric snack (confectionery snack); no lunch+caloric } \\
\text { snack; lunch+non-caloric snack (drink); no lunch + non- } \\
\text { caloric snack (drink) }\end{array}$ & $\begin{array}{l}\text { Digit span recall (forwards and backwards). Assess- } \\
\text { ment } 15 \text { min after eating snack }\end{array}$ & $\begin{array}{l}\text { Subjects recalled more digits in the backward digit span test after } \\
\text { the caloric snack than after the non-caloric snack }\end{array}$ & $\begin{array}{l}\text { Practice effects observed. Pre-lunch perfor- } \\
\text { mance not assessed (in both experiments) }\end{array}$ \\
\hline $\begin{array}{l}\text { Parker and } \\
\text { Benton (16) }\end{array}$ & $\begin{array}{l}33 \text { university students } \\
(17 \mathrm{M}, 16 \mathrm{~F}) \text {, mean age } \\
21 \text { years }\end{array}$ & 2 conditions: no breakfast; milk-based nutritional beverage & $\begin{array}{l}\text { Spatial memory. Immediate recall. Assessment } 2 \mathrm{~h} \\
\text { after breakfast }\end{array}$ & $\begin{array}{l}\text { Subjects who ate a breakfast took less time to finish memory } \\
\text { tasks than subjects who did not have breakfast. No effect of } \\
\text { breakfast on number of errors }\end{array}$ & Between subjects \\
\hline $\begin{array}{l}\text { Smith et al. } \\
\text { (17) }\end{array}$ & $\begin{array}{l}48 \text { university students } \\
(24 \mathrm{M}, 24 \mathrm{~F})\end{array}$ & $\begin{array}{l}4 \text { conditions: } 3 \text { course meal }(1200-1500 \mathrm{kcal})+\text { decaffei- } \\
\text { nated drink; } 3 \text { course meal }(1200-1500 \mathrm{kcal})+\text { caffeinated } \\
\text { drink; no meal + decaffeinated drink; no meal + caffeinated } \\
\text { drink }\end{array}$ & $\begin{array}{l}\text { Free recall task. Delayed recognition memory task. } \\
\text { Assessment before the meal and } 90 \text { and } 180 \text { min after } \\
\text { the start of the meal }\end{array}$ & No effects on memory tasks & $\begin{array}{l}\text { Effects were different to those observed after } \\
\text { lunch or breakfast }\end{array}$ \\
\hline
\end{tabular}

M: male; F: female; LF: low fat; HF: high fat; MF: medium fat; CHO: carbohydrates; LCHO: low carbohydrate; HCHO: high carbohydrate; MCHO: medium carbohydrate. 


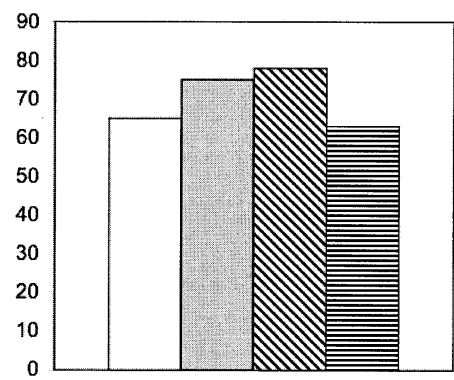

Fig. 2. Percentage of trigrams recalled as a function of blood glucose and change in blood glucose during the task. (Adapted from Martin \& Benton, 1999).

condition for both the critical flicker fusion threshold (CFFT) and memory performance. Poorer performance may be due to a lack of available energy, and consequently lower blood glucose.

Reaction time tasks appear to be sensitive to changes in blood glucose. Following a glucose drink, blood glucose level correlated with improved decision time (18). Poorer performance was associated with slower removal of glucose from the blood. However, glucose administration leaves unaltered the performance on digit span, tests of attention and motor function (3).

Test difficulty influences the apparent effects of glucose on cognition. More difficult tests produce a high cognitive demand. Thus, glucose reportedly enhances memory and some aspects of attention in normal adults, if tests are cognitively demanding. Cognitive demand increases glucose uptake (20). In one study, $25 \mathrm{~g}$ glucose was administered and memory performance was tested after either serial sevens (a highly demanding task) or a control task (20). Both tasks were followed by word retrieval (verbal fluency). Glucose consumption improved performance on serial sevens and verbal fluency. Peripheral measures of blood glucose decreased under the high cognitive load. This suggests that intense cognitive processing leads to increased neural glucose utilization. In addition, evidence from positron emission tomography (PET) suggests that increased neural activity (e.g. learning a complex visuospatial motor task or verbal working memory) is associated with an increased use of glucose by the brain (21). That frontal lobe functioning is enhanced by glucose suggests an increased supply of glucose to brain areas involved in memory tasks $(20,21)$. Alternatively (or additionally), glucose may activate the release of ACh during learning, to enhance memory performance.

\section{Effects of carbohydrates at lunchtime}

No studies examining the effects of $\mathrm{CHO}$ at lunchtime have described the glycaemic index (GI) of the dietary manipulation. Manipulations of the proportions of $\mathrm{CHO}$ and fat in lunchtime meals have produced diverse outcomes; some have shown $\mathrm{CHO}$ to produce a better effect on performance than fat, while others have shown the converse (13, $14,22,23)$. Higher than usual proportions of fat or CHO may induce drowsiness or uncertainty, or potentially affect cognitive efficiency and motor performance (24).

Two studies $(23,25)$ compared the performance effects of high-CHO and high-protein meals. One found no effect of either meal on auditory reaction time, irrespective of whether the meal was given at breakfast or lunch (23). The other, in contrast, found that auditory reaction time was slower following the $\mathrm{CHO}$ lunch (25). The nature of the $\mathrm{CHO}$ and the timing of ingestion may be important in explaining the different effects in each study.

\section{Performance and the glycaemic index of foods}

Fischer et al. (26) used test meals (400 kcal) of either pure $\mathrm{CHO}$ (glucose, maltodextrin and rice starch), protein or fat (a combination of saturated and unsaturated fatty acids). Protein ingestion resulted in better attention and efficiency on tasks, which was concomitant with higher metabolic activation. There were different effects of $\mathrm{CHO}$ and protein in peripheral versus central tasks. Thus, $\mathrm{CHO}$ resulted in relatively low peripheral performance and better central performance, while the opposite pattern was observed following protein ingestion. Fat had no effect on reaction time. The authors attributed this to the steady plasma concentrations of glucose, insulin and glucagon, as produced by fat consumption. Moreover, they observed that the ingestion of pure $\mathrm{CHO}$ induced slower reaction time, while pure protein produced faster reaction times on demanding complex (but not simple) reaction-time tasks. This effect was only apparent $2 \mathrm{~h}$ after ingestion, reflecting differences in the absorption and metabolism of the two macronutrients. The first hour following ingestion saw the reverse pattern.

\section{Glucose tolerance}

Glucose tolerance (i.e. the ability to take up glucose from the bloodstream to tissues) is posited as important in mediating nutritional effects on cognitive function. There are substantial individual 
differences in glucose tolerance (27), as reflected in the susceptibility to impairment of cognitive performance. Subjects with higher levels of blood glucose and good glucose tolerance respond most efficiently to the demand of cognitive tasks (19). The threshold for impairment of cognitive tasks has been found to be within a range of $2.2-2.8 \mathrm{mmol}$ $1^{-1}$ (28). However, some individuals maintained normal performance at below $2.2 \mathrm{mmol}^{-1}$, while others showed disruption of function at $4 \mathrm{mmol}$ $1^{-1}$. It has been suggested that cognitive disruption at higher glucose levels occurs in non-diabetics, whose hypoglycaemic symptoms are relieved by food intake (19). Glucose tolerance can be improved by exercise and frequent, small meals, but effects on cognitive performance remain unknown. The response to hypoglycaemia is greater in males. Cognitive impairment is associated with impaired glucose tolerance and hyperinsulinaemia in nondiabetic samples of elderly persons (29). Some studies suggest that stable performance is related to balanced glucose metabolism and state of metabolic activation (26). This may be mediated via an action of glucose on the cholinergic system (30).

\section{The post-lunch dip}

The consensus view is that daytime sleepiness, or the afternoon decline in mental alertness (the PLD), is a circadian rhythm. This phenomenon has sparked considerable research interest in many European countries, given its association with a loss of work efficiency.

A review of six studies examining circadian rhythms in mental performance (31) deficits (particularly those related to attention) in the early afternoon was reported. Increasing meal size at lunchtime produces more momentary lapses of attention. This PLD effect is abolished by caffeine (32). Performance on sustained attention tasks is impaired in the early afternoon, compared with the late morning, irrespective of food consumption (22). It is seemingly difficult to disentangle the effects of lunch consumption from the rhythmic effects underlying the PLD. Declines could simply reflect the effect of a negative energy balance or a lack of available glucose.

Circadian patterns in mood may interact with food intake. Glucose and cortisol secretion (as responses to food intake) varies across the day. For example, alertness peaks in mid-morning, then falls throughout the day (33). The natural rhythm of cortisol exhibits diurnal variation. These rhythms may explain the different effects of meals on mood and performance across the day. Thus, the effects of alertness-enhancing foods are most likely to be detected if they are ingested at a time when alertness is naturally declining, and cognitive capacity is challenged by an appropriate cognitive test. For instance, the beneficial effects of afternoon snacks do not occur if snacks are given in the late morning (15). Therefore, task selection in the design of a test battery should embrace these considerations. Furthermore, physiological measures, e.g. blood glucose, insulin and fatty acids, are important biomarkers of the metabolic state of the individual following food consumption.

Dietary interventions that potentially modulate the PLD are of research interest. Varying the GI offers a considerable opportunity for functional food development, with potentially positive effects on the extent and timing of post-lunch inefficiency. Maintaining blood glucose appears to be beneficial. This can inform advice about breakfast consumption, snacking and the development of functional foods, which modulate blood glucose. The effect of $\mathrm{CHO}$ at lunchtime is therefore an important consideration.

\section{Methodological considerations}

Cognitive demand reportedly increases the uptake of glucose. The order of tests in a battery therefore warrants careful consideration and piloting with respect to the proposed intervention. A lack of effect may occur because the most demanding task is placed in a particular order in the battery (e.g. first or at the peak of a nutrient effect), when resources are most plentiful. Thus, the timing of tests after consumption and the relative order of tests within a battery must be considered in conjunction with data about the GI of the food, details of its likely course of digestion, and metabolism. Measurements of blood glucose immediately after cognitive testing may reflect arousal or stress produced by the cognitive tests (perhaps exacerbated by evaluation or apprehension of the participants), rather than an exclusive response to a nutrient intervention.

\section{Conclusion}

This article has summarized some of the evidence linking dietary interventions (mainly $\mathrm{CHO}$ ) and cognitive performance. Dietary adjustments of glu- 
cose availability influence performance, but the situation is not simple. Salient effects are seen in studies using large glucose loads. The effects of foods, however, are less precise. Individual differences in responses to foods and in glucose profiles are marked, and important in explaining the effects of interventions on cognitive performance and subjective state. These factors mitigate against the demonstration of clear effects on cognition. Moreover, given that cognitive function is strongly protected against disruption, innovative and carefully designed studies are imperative in demonstrating the subtle effects of food manipulations, and in examining the potential for the development of functional foods.

\section{Acknowledgements}

The PsychoBiology Group at the University of Leeds is one of the partners in a VINNOVA project (341-2001-05617) examining the interrelationships among diet, metabolism, mood and cognitive performance.

\section{References}

1. Bellisle F, Blundell JE, Dye L, et al. Functional food science and behaviour and psychological functions. Br J Nutr 1998; 80: 173-93.

2. Strachan MW, Deary IJ, Ewing FM, Frier BM. Is type II diabetes associated with an increased risk of cognitive dysfunction? A critical review of published studies. Diabetes Care 1997; 20: 438-45.

3. Manning CA, Hall JL, Gold PE. Glucose effects on memory and other neuropsychological tests in elderly humans. Psychol Sci 1990; 1: 307-11.

4. Hall JL, Gonder-Frederick LA, Chewning WW, et al. Glucose enhancement of performance on memory tests in young and aged humans. Neuropsychologia 1989; 27: 1129-38.

5. Benton D, Parker PY. Breakfast blood glucose and cognition. Am J Clin Nutr 1998; 67: 772-778S.

6. Deijen JB, Wientjes CJE, Vullinghs HFM, et al. Tyrosine improves cognitive performance and reduces blood pressure in cadets after one week of a combat training course. Brain Res Bull 1999; 48: 203-9.

7. Benton D, Owens D, Parker PY. Blood glucose memory and attention. Neuropsychologia 1994; 32: 595-607.

8. Martin PY, Benton D. The influence of a glucose drink on a demanding working memory task. Physiol Behav 1999; 67: 69-74.

9. Metzger MM. Glucose enhancement of a facial recognition task in young adults. Physiol Behav 2000; 68: 54953.

10. Green MW, Taylor M, Elliman NA, Rhodes O. Placebo expectancy effects in the relationship between glucose and cognition. Psychological Medicine; in press.
11. Foster JK, Lidder PG, Sünram SI. Glucose and memory: fractionation of enhancement effects? Psychopharmacology 1998; 137: 259-70.

12. Kelly TH, Foltin RW, Rolls BJ, Fischman MW. Effect of meal macronutrient and energy content on human performance. Appetite 1994; 23: 97-111.

13. Lloyd HM, Green MW, Rogers PJ. Mood and cognitive performance effects of isocaloric lunches differing in fat and carbohydrate content. Physiol Behav 1994; 56: $51-7$.

14. Lluch A, Dye L, Blundell JE. Effects of nutrient manipulations on motivation to eat and performance in high fat and low fat phenotypes. Appetite 2000; 35: 202.

15. Kanarek RB, Swinney D. Effects of food snacks on cognitive performance in male college students. Appetite 1990; 14: 15-27.

16. Parker PY, Benton D. Blood glucose levels selectively influence memory for word lists dichotically presented to the right ear. Neuropsychologia 1995; 33(7): 843-54.

17. Smith AP, Maben A, Brockman P. Effects of evening meals and caffeine on cognitive performance, mood and cardiovascular functioning. Appetite 1994; 22: $57-$ 65.

18. Benton D, Owen SD. Blood glucose and human memory. Psychopharmocology 1993; 113: 83-8.

19. Donohoe RT, Benton D. Cognitive functioning is susceptible to the level of blood glucose. Psychopharmocology 1999; 145: 378-85.

20. Scholey AB, Harper S, Kennedy DO. Cognitive demand and blood glucose. Physiol Behav 2001; 73: 58592.

21. Jonides J, Schumacher EH, Smith EE, et al. Verbal working memory load affects regional brain activation as measured by PET. J Cogn Neurosci 1997; 9: 46275 .

22. Smith AP, Miles C. Effects of lunch on selective and sustained attention. Neuropsychobiology 1986; 16: $117-$ 20.

23. Spring B, Maller O, Wurtman J, et al. Effects of protein and carbohydrate meals on mood and performance: interactions with sex and age. J Psychiatr Res 1983; 17: 155-167R.

24. Reid M, Hammersley R. The effects of carbohydrates on arousal. Nutr Res Reviews 1999; 12: 3-23.

25. Lieberman HR, Spring B, Garfield GS. The behavioural effects of food constituents: strategies used in studies of amino acids, protein, carbohydrates and caffeine. Nutr Rev 1986; 44: S61-9.

26. Fischer K, Colombani PC, Langhans W, Wenk C. Cognitive performance and its relation to postprandial metabolic changes after different macronutrient ingestion in the morning. Br J Nutr 2001; 85: 393-403.

27. Lev-Ran A, Anderson RW. The diagnosis of postprandial hypoglycemia. Diabetes 1981; 30: 996-9.

28. Widom B, Simonson DC. Glycemic control and neurophysiologic function during hypoglycemia in patients with insulin dependent diabetes mellitus. Ann Intern Med 1990; 112: 904-12. 
29. Kalmijn S, Feskens EJM, Launer LJ, Kromhout D. Polyunsaturated fatty acids, antioxidants and cognitive function in very old men. Am J Epidemiol 1997; 145: $33-41$.

30. Owens DS, Benton D. The impact of raising blood glucose on reaction times. Neuropsychobiology 1994; 30: 106-13.

31. Monk TH, Folkard S. Shiftwork and performance. In: Folkard S, Monk TH, eds. Hours of work: temporal factors in work-scheduling. Chichester: Wiley; 1985. p. $50-62$.

32. Smith AP, Rusted JM, Eaton-Williams P, et al. Effects of caffeine given before and after lunch on sus- tained attention. Neuropsychobiology 1991; 23(3): 160-3.

33. De Castro JM. Circadian rhythms of the spontaneous meal pattern, macronutrient intake, and mood of humans. Physiol Behav 1987; 40: 437-46.

John Blundell

PsychoBiology Group

School of Psychology

University of Leeds

Leeds LS2 9JT, UK

E: mail: Johneb@psychology.leeds.ac.uk 